\title{
Beban Cemar Fosfor dari Kegiatan Budidaya dan Dampaknya Terhadap Status Kesuburan Danau Maninjau, Sumatera Barat
}

\section{The load of Phosphorus from Cultivation Activities and Its Impact on Trophic State of Lake Maninjau, West Sumatera}

\author{
Andri Warsa dan Joni Haryadi \\ Balai Riset Pemulihan Sumber Daya Ikan Padang Sumatera Barat \\ (Diterima tanggal 3 Agustus 2018, Disetujui tanggal 27 Mei 2019)
}

\begin{abstract}
ABSTRAK
Danau Maninjau yang terletak di Kabupaten Agam, Sumatera Barat merupakan badan air dengan keanekaragaman ikan yang tinggi. Kegiatan perikanan budidaya dalam Keramba Jaring Apung (KJA), yang merupakan kegiatan sekunder di Danau Maninjau, telah melebihi daya dukung ekologi. Sisa pakan dan hasil metabolime dari ikan yang dipelihara merupakan sumber fosfor total (P) yang masuk ke perairan. Penelitian ini bertujuan untuk mengetahui beban P dari kegiatan budidaya dan dampaknya terhadap status kesuburan perairan di Danau Maninjua, Sumatera Barat. Penelitian dilakukan pada bulan Februari dan September 2016, dimana pengambilan contoh air dilakukan pada enam stasiun pengamatan. Data parameter kegiatan budidaya diperoleh dari wawancara dan penelusuran pustaka. Hasil penelitian menunjukkan bahwa beban masukkan P dari kegiatan budidaya sebesar 693,4 tonP/tahun sedangkan dari daerah tangkapan air sebanyak 20 tonP/tahun. Dampak beban P dari kegiatan budidaya menyebabkan perairan Danau Maninjau menjadi sangat subur (Hipertrofik).
\end{abstract}

Kata kunci: budidaya, Beban P, Danau Maninjau, eutrofikasi

\section{ABSTRACT}

Lake Maninjau located in Agam District, West Sumatera is a water body with high fish diversity. The aquaculture activity at floating net cage, which is the secondary utilization in Lake Maninjau, has exceeded the limit of ecology carrying capacity. Letfover feed and fish metabolism residue were the resources of phosphorus $(P)$ loading to the water body. The objective of this research was to determine the P loading from aquaculture and its impact for Lake Maninjau trophic state. The research was conducted on February and September 2016, while the sampling was carried out at six stations. The data of aquaculture parameters were obtained from interview with farmer and desk study. The result of the research shown that $P$ loading from aquaculture and catchment area were 693,4 and 20 tonP/year, respectively. The effect of P loading from aquaculture activity has caused trophic state of Lake Maninjau became hypertrophic.

Keywords: aquaculture, loading P, Lake Maninjau, eutrophication

\section{PENDAHULUAN}

Danau Maninjau dengan luas 9.950 ha dan kedalaman rata-rata $105 \mathrm{~m}$ secara administratif terletak di Kecamatan Tanjung Raya Kabupaten Agam, Sumatera Barat. Danau ini merupakan sarana untuk pembangkit tenaga listrik dengan kapasitas 205 GWH per tahun.
Fungsi lain dari danau ini sebagai sumber air irigasi, perikanan tangkap dan budidaya serta pariwisata (Yuniarti et al., 2009). Danau Maninjau memiliki keragaman jenis ikan yang tinggi dimana ditemukan sebanyak 14 spesies ikan (Roesma, 2013). Ikan bada 
(Rasbora argyrotaenia) merupakan jenis ikan yang dominan tertangkap selain betutu (Oxyeleotris marmorata), baung (Mystus spp) dan nila (Oreochromis niloticus) (Yuniarti et al., 2010). Selain berasal dari kegiatan perikanan budidaya, sumber percemaran di Danau Maninjau berasal dari limbah rumah tangga dan pertanian (Fakhrudin, 2003). Aktivitas perikanan di Danau Maninjau didominasi oleh kegiatan perikanan budiaya yang berkembang dengan pesat dan telah melebihi daya dukung perairan (Sulastri et al., 2012). Kegiatan budidaya merupakan kegiatan perikanan dengan keuntungan yang besar menyebabkan pesatnya pertambahan jumlah KJA yang beroperasi pada suatu badan air (Tamba et al., 2014; Sitompul et al., 2015). Pada tahun 2008, Produksi ikan budidaya di Danau Maninjau sebesar 2.885 ton/tahun dengan nilai ekonomi Rp 21,6 milyar (Yuniarti et al., 2009). Daya dukung kegiatan budidaya ikan di Danau Maninjau sebesar 15.433 ton/ tahun atau setara dengan 8.230 petak KJA (Syandri et al., 2016). Jumlah KJA yang beroperasi telah melebihi daya dukung ekologi perairan sebesar $174 \%$. Hal ini berdampak pada akumulasi bahan organik yang berasal dari pakan yang digunakan dalam kegiatan budidaya (Neumeier et al., 2007; Suyani et al., 2016). Perkembangan yang tidak terkendali telah menimbulkan dampak negatif bagi budidaya itu sendiri (Triyanto et al., 2005).

Pemberian pakan yang tidak efisien dalam kegiatan budidaya di Danau Maninjau menyebabkan banyaknya pakan yang terbuang dan terakumulasi di dasar perairan (Afrin et al., 2015). Dampak yang timbul adalah peningkatan kesuburan perairan di Danau Maninjau sehingga sering terjadinya kematian massal ikan (Nasution et al., 2011) serta pertumbuhan fitoplankton yang tidak terkendali (Garno et al., 2002). Dampak lain yang timbul akibat adanya peningkatan kesuburan adalah penurunan produktivitas produksi ikan budidaya (Krismono, 1992). Hasil penelusuran pustaka menunjukkan belum adanya kajian secara langsung mengenai dampak beban fosfor (TP) dari kegiatan budidaya terhadap status kesuburan perairan. Oleh karena itu perlu adanya suatu kajian untuk mengetahui dampak beban TP yang dihasilkan dari kegiatan budidaya terhadap kesuburan perairan. Tujuan penelitian ini adalah untuk menghitung beban total fosfor (TP) dari kegiatan budidaya dan dampaknya terhadap kesuburan perairan di Danau Maninjau, Sumatera Barat.

\section{METODOLOGI}

\section{Waktu dan Lokasi}

Penelitian dilakukan di Danau Maninjau pada Februari dan September 2016. Pengambilan contoh air dilakukan pada enam stasiun yaitu (Gambar 1) pada kedalaman 0,5 m dari permukaan dengan menggunakan Kemmerer Water Sampler 3,1 L dengan metode sampling berstrata (Johnson \& Nielson, 1985). Contoh air yang diperoleh kemudian dimasukkan ke dalam botol polyetilen $500 \mathrm{~mL}$ dan diberi pengawet. Untuk analisa fosfor total contoh air diberi pengawet Asam Sulfat pekat hingga $\mathrm{pH} 2$, sedangkan untuk analisa klorofil- $a$ diberi pengawet $\mathrm{MgCO}_{3}$. Kecerahan perairan diukur dengan menggunakan Sechi disk (diameter $30 \mathrm{~cm}$ ) (APHA, 2005). Analisa klorofil-a dilakukan di Laboratorium Kimia Balai Penelitian Pemulihan Sumber Daya Ikan, sedangkan untuk parameter fosfor total 
dilakukan di Laboratoriun BBIA, Bogor. Untuk data hasil panen setiap petak dan jumlah pakan yang digunakan diperoleh dari wawancara dengan 15 pembudidaya. Wawancara dilakukan dengan bantuan kuisioner dengan metode purposive sampling methods (Palys, 2008). Jumlah petak KJA yang ada di Danau Maninjau dihitung berdasarkan peta citra dari googel earth tahun 2016.

Data produksi total ikan budidaya diperoleh dari Dinas Kelautan dan Perikanan, Kabupaten Agam dan Junaidi et al. (2013). Konsentrasi fosfor pada pakan dan ikan yang dibudidayakan diperoleh dari Syandri et al. (2016).

\section{Analisa data}

\section{Estimasi beban fosfor (TP)}

Perhitungan beban P dari kegiatan budidaya dihitung berdasarkan konsentrasi P pada pakan yang digunakan serta retensi P pada ikan yang dibudidayakan (Kibria et al., 1996). Beban cemar TP yang berasal dari kegiatan budidaya dihitung dengan persamaan Beveridge (2004) yaitu:

$$
\begin{aligned}
& \mathrm{LP}_{\text {ling }}=\mathrm{P}_{\text {pakan }}-\mathrm{P}_{\text {ikan }} \\
& \mathrm{LP}_{\text {pakan }}=\mathrm{RKP} \times \% \mathrm{P}_{\text {pakan }} \times 1000 \\
& \mathrm{LP}_{\text {ikan }}=\% \mathrm{P}_{\text {ikan }} \times 1000
\end{aligned}
$$

Keterangan:

$$
\begin{aligned}
& \mathrm{LP}_{\text {ling }}=\text { fosfor yang terbuang ke lingkungan (kgP/ton ikan) } \\
& \mathrm{LP}_{\text {pakan }}=\text { beban cemar TP dari pakan }(\mathrm{kgP} / \text { ton pakan) } \\
& \mathrm{LP}_{\text {ikan }}=\text { beban cemar TP dari ikan (kgP/ton ikan) } \\
& \mathrm{RKP}=\text { rasio konversi pakan } \\
& { }_{\mathrm{OP}}=\text { kakan } \\
& \mathrm{PP}_{\text {ikan }}=\text { konsentrasi fosfor total pada pakan }(\%)
\end{aligned}
$$

\section{Estimasi Konsentrasi TP, Klorofil- $a$ dan kecerahan}

Besarnya konsentrasi $\mathrm{P}$ di perairan ditentukan oleh besarnya beban cemar $\mathrm{P}$ dan hidromorfologi badan air yaitu luas, kedalaman dan volume air keluar (Flushing rate) (Badr \& Hussein, 2010). Dampak beban cemar P dari kegiatan budidaya terhadap parameter status kesuburan perairan yaitu total fosfor (Rast et al.,1983), klorofil-a (Jones et al., 1979) dan kecerahan (Lee et al. 1978)

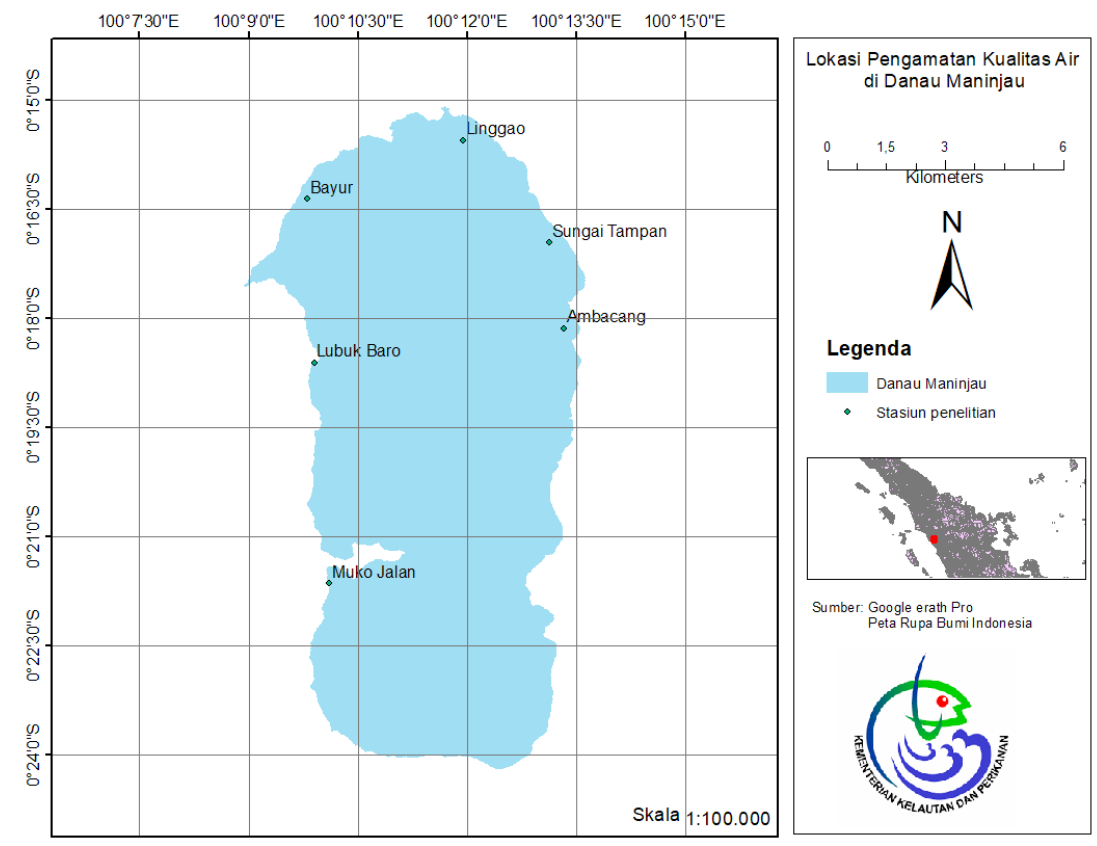

Gambar 1. Lokasi Pengamatan kualitas air di Danau Maninjau 
dihitung berdasarkan persamaan:

$$
\begin{array}{rll}
{[P]} & =1,81\left[\left(L(P) / q_{s}\right) /\left(1+\sqrt{t_{\mathrm{w}}}\right)\right]^{0,81} & \ldots \ldots \ldots(4) \\
\log [\mathrm{chlo}-a] & =0,76 \log \left[\left(\mathrm{L}(\mathrm{P}) / \mathrm{q}_{\mathrm{s}}\right) /\left(1+\sqrt{\tau_{\mathrm{w}}}\right)-0,259\right. & \ldots \ldots \ldots(5) \\
\log \mathrm{SD} & = & -0,359 \log \left[\left(\mathrm{L}(\mathrm{P}) / \mathrm{q}_{\mathrm{s}}\right) /\left(1+\sqrt{\tau_{\mathrm{w}}}\right)+0,925\right.
\end{array}
$$

Keterangan:

$$
\begin{array}{rll} 
& = & \text { konsentrasi fosfor total diperairan }\left(\mu \mathrm{g} \mathrm{L}^{-1}\right) \\
& = & \text { beban cemar fosfor total ke badan air } \\
& & \left(\mathrm{kgP} \mathrm{km}^{-2} \text { tahun }^{-1}\right) \\
\mathrm{t}_{\mathrm{w}} & = & \text { waktu tinggal air (tahun) } \\
\mathrm{Z} & = & \text { kedalaman rata-rata }(\mathrm{m}) \\
\mathrm{Chl}-\mathrm{a} & = & \text { konsentrasi klorofil- } a\left(\mu \mathrm{g} \mathrm{L}^{-1}\right) \\
\mathrm{SD} & = & \text { kecerahan }(\mathrm{m}) \\
\mathrm{qs} & = & \begin{array}{l}
\text { rasio kedalaman rata-rata terhadap waktu } \\
\text { tinggal air }\left(\mathrm{m} \mathrm{tahun}^{-1}\right)
\end{array}
\end{array}
$$

Status kesuburan perairan

Kesuburan perairan dianalisa

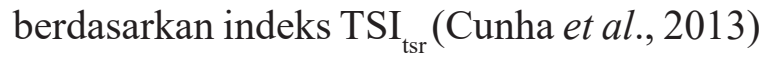
dengan menggunakan persamaan sebagai berikut:

$$
\begin{array}{ll}
\operatorname{TSI}(\mathrm{TP})_{\mathrm{tsr}} & =10\left[6-\left(\frac{-0,27637 \ln \mathrm{TP}+1,329766}{\ln 2}\right)\right] \\
\operatorname{TSI}(\mathrm{CHL})_{\mathrm{tsr}} & =10\left[6-\left(\frac{-0,2512 \ln \mathrm{CHL}+0,842257}{\ln 2}\right)\right] \\
\operatorname{TSI}_{\mathrm{tsr}} & =1 / 2\left(\mathrm{TSI}(\mathrm{TP})_{\mathrm{tsr}}+\mathrm{TSI}(\mathrm{CHL})_{\mathrm{tsr}}\right)
\end{array}
$$

\section{Keterangan:}

$$
\begin{array}{lll}
\mathrm{TP} & = & \text { Konsentrasi fosfor total }(\mu \mathrm{g} / \mathrm{L}) \\
\mathrm{CHL} & = & \text { Konsentrasi klorofil }-a(\mu \mathrm{g} / \mathrm{L}) \\
\mathrm{TSI}_{\text {tsr }} & =\text { Indeks status kesuburan }
\end{array}
$$

Status trofik berdasarkan indeks $\mathrm{TSI}_{\mathrm{tsr}}$ diklasifikasikan sebagai berikut TSI $_{\text {tsr }} \leq 51,1$ : ultraoligotrofik; TSI $_{\text {tsr }}$ 51,2-53,1: oligotrofik; TSI $_{\text {tsr }}$ 53,2-55,7: mesotrofik; TSI $_{\text {tsr }}$ 55,8-58,1: eutrofik; TSI $_{\text {tsr }}$ 58,2-59,0: supereutrofik dan $\mathrm{TSI}_{\text {tsr }}: \geq 59,1$ : hipereutrofik.

Status kesuburan Danau Maninjau ditentukan berdasarkan estimasi parameter fosfor total, klorofil- $a$ dan kecerahan. Parameter tersebut dibandingkan dengan nilai status kesuburan pada Tabel 1. (Smith et al. 1999).
Tabel 1. Kesuburan perairan waduk

\begin{tabular}{lccc}
\hline Status trofik & $\begin{array}{c}\text { Fosfor total } \\
\left(\mathrm{mg} \mathrm{m}^{-3}\right)\end{array}$ & $\begin{array}{c}\text { Klorofil- } a \\
\left(\mathrm{mg} \mathrm{m}^{-3}\right)\end{array}$ & $\begin{array}{c}\text { Kecerahan } \\
(\mathrm{m})\end{array}$ \\
\hline Oligotrofik & $<10$ & $<3,5$ & $>4$ \\
Mesotrofik & $10-30$ & $3,5-9$ & $2-4$ \\
Eutrofik & $30-100$ & $9-25$ & $1-2$ \\
Hipertrofik & $>100$ & $>25$ & $<2$ \\
\hline
\end{tabular}

Beban cemar yang berasal dari luar badan air dihitung berdasarkan tata guna lahan pada daerah tangkapan air (DTA) (Ryding \& Rast, 1989). Masing-masing tata guna lahan menyumbang fosfor total ke dalam badan air dengan besaran yang berbeda. Pendekatan koefisien ekspor dapat digunakan untuk memprediksi beban cemar TP dari DTA yang berasal dari sumber nonpoint (Jhones 1996; De Anda et al. 2001). Beban cemar fosfor total dari tata guna lahan dihitung dengan persamaan Jorgensen (1988):

$$
I_{p l}=\sum_{i=1}^{m} A_{l} x E_{p}
$$

Keterangan:

$$
\begin{aligned}
& =\text { fosfor total dari setiap tata guna lahan }(\mathrm{g} \text { tahun } \\
\mathrm{m} & =\text { jumlah dari tipe tata guna lahan } \\
& =\text { luas tata guna lahan }\left(\mathrm{m}^{2}\right) \\
& =\text { koefisien ekspor fosfor total }\left(\mathrm{g} \mathrm{m}^{-2} \text { tahun }^{-1}\right)
\end{aligned}
$$

Koefisien ekspor yang digunakan dalam perhitungan diperoleh dari penelusuran pustaka. Nilai koefisien ekspor P dari masingmasing tata guna lahan disajikan pada Tabel 2.

Tabel 2. Koefisien ekspor dari tata guna lahan

\begin{tabular}{cc}
\hline Tata guna lahan & Koefisen ekspor $(\mathrm{g} / \mathrm{m} /$ tahun $)$ \\
\hline Pemukiman & 0,1 \\
Rumput & 0,025 \\
Pertanian & 0,09 \\
Hutan & 0,01 \\
Kebun & 0,3 \\
\hline Sumber: Rast \& Lee 1983
\end{tabular}




\section{HASIL DAN PEMBAHASAN}

KJA yang beroperasi di Danau Maninjau berjumlah 22.600 petak dengan ikan yang dibudidayakan adalah ikan nila (Oreochromis niloticus). Jumlah KJA ini mengalami peningkatan jika dibandingkan dengan jumlah KJA yang beroperasi tahun 2015 yaitu 16.120 petak (Syandri et al., 2016). Beban cemar TP yang berasal dari kegiatan budidaya sebesar 693,4 tonP/tahun (Tabel 3). Besarnya beban TP yang berasal dari kegiatan budidaya sebesar 69-86\% dari kandungan TP dalam pakan (Lazzari \& Baldisserotto, 2008).

Tabel 3. Perhitungan beban P dari budidaya ikan nila di Danau Maninjau

\begin{tabular}{llll}
\hline No & \multicolumn{1}{c}{ Parameter } & \multicolumn{1}{c}{ Satuan } & \multicolumn{1}{c}{ Nilai } \\
\hline 1. & Padat tebar & $\mathrm{kg} /$ petak/siklus & $50-250$ \\
2. & Jumlah pakan & $\mathrm{kg} /$ siklus/petak & 1.424 \\
3. & Jumlah panen & $\mathrm{kg} /$ siklus/petak & 1.00 \\
4. & Konversi pakan (RKP) & & 1,60 \\
5. & TP pakan & $\%$ & 1,2 \\
6. & TP ikan nila & $\%$ & 0,377 \\
7. & Beban TP & $\mathrm{kg} \mathrm{P/ton} \mathrm{ikan}$ & 15,43 \\
8. & Produksi & ton ikan/tahun & 45.2000 \\
9. & Total beban TP & Ton P/tahun & 705,1 \\
\hline
\end{tabular}

Sumber: Parameter 1-6 (Syandri et al., 2016); 7-9 hasil perhitungan

Hasil penelitian menunjukkan beban cemar TP dari kegiatan budidaya di Danau Maninjau sebesar 14,61 kg/ton. Beban cemar TP untuk setiap petak KJA ini lebih kecil jika dibandingkan dengan hasil uji coba dari Syandri et al (2018) yaitu sebesar $20 \mathrm{~kg} /$ tahun ikan. Namun beban cemar TP dalam satu tahun lebih besar jika dibandingkan dengan hasil penelitian Syandri et al. (2016) yaitu 294,2 ton/tahun. Hasil penelitian Fakhrudin (2003) menunjukkan bahwa beban TP yang berasal dari kegiatan budidaya di Danau Maninjau sebesar 2000-3000 ton/ tahun dengan konsentrasi $\mathrm{P}$ pada pakan sebesar 1,3\% dan nilai FCR sebesar 2,5. Hal ini berkaitan dengan jumlah KJA yang beroperasi dan produksi total ikan budidaya yang lebih kecil jika dibandingkan dengan penelitian ini. Beban cemar TP dari kegiatan budidaya dipengaruhi oleh komposisi $\mathrm{N}$ dan TP pada pakan serta produksi total ikan yang dihasilkan dalam kegitan budidaya tersebut (Kibria et al., 1996). Beban cemar TP yang dapat ditampung oleh Danau Maninjau pada kondisi perairan menjadi mesotrofik adalah 223,4 ton/tahun (Machbub, 2010). Hal ini menunjukkan bahwa beban $\mathrm{P}$ akibat kegiatan budidaya ini telah melebihi kemampuan pulih diri badan air pada kondisi mesotrofik. Beban TP yang masuk ke perairan Danau Maninjau telah melebihi kemampuan asimilasi perairan Danau Maninjau (Marganof et al., 2007).

Beban cemar TP yang berasal dari aktivitas budidaya berdampak pada peningkatan status kesuburan perairan di Danau Maninjau (Sulastri et al., 2012). Estimasi konsentrasi TP rataan di perairan Danau Maninjau berdasarkan beban cemar TP dari kegiatan budidaya sebesar $596 \mu \mathrm{g} / \mathrm{L}$ dengan konsentrasi klorofil-a 41,4 $\mu \mathrm{g} / \mathrm{L}$ dan nilai kecerahan 1,1 m (Tabel 4). Konsentrasi TP pada suatu badan air dipengaruhi oleh besarnya beban cemar $\mathrm{P}$ ke dalam badan air (Brett \& Benjamin, 2008). Parameter TP, kolrofil- $a$ dan kecerahan hasil estimasi menunjukkan bahwa beban cemar $\mathrm{P}$ dari kegiatan budidaya menyebabkan perairan Danau Maninjau menjadi sangat subur (hipertrofik). Beban TP yang berasal dari kegiatan budidaya berdampak pada peningkatan status kesuburan perairan menjadi hipereutrofik dengan nilai TSI tsr $_{\text {63 }}$,3. Kegiatan budidaya nila di Waduk North Shoa di Afrika berdampak pada peningkatan kesuburan 
perairan menjadi eutrofik-hipertrofik (Ahmed et al., 2010; Degefu et al., 2011). Hal ini disebabkan beban cemar Pyang melebihi daya dukung perairan (True et al., 2004).

Tabel 4. Estimasi konsentrasi P, Klorofil-a dan kecerahan

\begin{tabular}{llll}
\hline No & Parameter & Satuan & Nilai \\
\hline 1. & Luas (A) & $\mathrm{Ha}$ & $9.737,5$ \\
2. & Volume (V) & juta $^{3}$ & $10.226,2$ \\
3. & Kedalaman rata-rata $(\mathrm{z})$ & $\mathrm{m}$ & 105,2 \\
4. & Waktu tinggal air & tahun & 25,05 \\
5. & Laju pembilasan & per tahun & 0,039 \\
6. & Total P & $\mu \mathrm{g} / \mathrm{L}$ & 540 \\
7. & Klorofil- $a$ & $\mu \mathrm{g} / \mathrm{L}$ & 41,4 \\
8. & Kecerahan & $\mathrm{m}$ & 1,1 \\
\hline
\end{tabular}

Sumber: Parameter 1-5 (Fakhrudin, 2003); 6-7 hasil perhitungan

Hasil pengukuran pada contoh air menunjukkan bahwa konsentrasi fosfor total, klorofil-a masing-masing adalah 680-820 $\mu \mathrm{g} / \mathrm{L}$ dengan rata-rata $743 \mu \mathrm{g} / \mathrm{L}$ dan 33,97-74,80 $\mu \mathrm{g} / \mathrm{L}$ dengan rata-rata $47,89 \mu \mathrm{g} / \mathrm{L}$ serta nilai kecerahan berkisar 0,9-1,3 $\mathrm{m}$ dengan rata-rata 1,08 m. Beban nutrien dari kegiatan budidaya berdampak pada konsentrasi nutrient dan klorofil-a (Guo \& Li, 2003). Jika dibandingkan dengan hasil pengukuran, konsentrasi total $\mathrm{P}$ dan klorofil-a hasil estimasi lebih rendah. Hal ini disebabkan oleh belum dimasukkanya beban cemar TP dari air hujan dan air tanah. Hasil penelitian Lukman et al (2013) menunjukkan bahwa kecerahan Danau Maninjau berkisar 0,4-1,7 m. Hasil analisa berdasarkan indeks Storet menunjukkan bahwa kualitas air Danau Maninjau termasuk kedalam kategori tercemar berat dengan kecerahan dan klorofil- $a$ masing-masing 0,7$1,1 \mathrm{~m}$ dan $81,1-155 \mathrm{mg} / \mathrm{m}^{3}$ (Aries et al., 2015) dengan tingkat kesuburan perairan tinggi (eutrofik) (Junaidi et al., 2013; Sulastri et al., 2016). Kondisi kualitas air menyebabkan sering terjadinya kematian massal ikan serta penurunan produkktivitas KJA di Danau Maninjau (Syandri et al., 2015).

Tata guna lahan pada daerah tangkapan air disekitar Danau Maninjau didominasi oleh kawasan hutan. Beban cemar TP dari daerah tangkapan air berdasarkan tata guna lahan sebesar $20.725,9 \mathrm{~kg} /$ tahun atau setara dengan 20,7 tonP/tahun (Tabel 5). Beban cemar TP dari daerah tangkapan juga dapat dihitung berdasarkan konsentrasi TP dan debit air sungai yang masuk ke dalam danau (Ryding \& Rast, 1989). Perhitungan besaran beban TP berdasarkan konsentrasi TP dan debit air sungai (Fakhrudin, 2003). Debit air masuk ke Danau Mnainjau yang berasal dari sungai inlet rata-rata sebesar 54,8 L/det dengan konsentrasi TP rata-rata 0,051 mg/L. Beban cemar TP dari sungai inlet sebesar 27 ton/tahun. Estimasi beban cemar TP dari DTA ini lebih kecil dari hasil penelitian Machbub (2010) yaitu 70,8 tonP/tahun. Perhitungan beban cemar TP dari daerah tangkapan air disajikan pada Tabel 5.

Tabel 5. Perhitungan beban masukan $\mathrm{P}$ dari daerah tangkapan air

\begin{tabular}{ccc}
\hline Tata guna lahan & Luasan (ha) & Beban P (kg P/tahun) \\
\hline Hutan & $5.436,8$ & 543,7 \\
Ladang & $1.827,4$ & $5.482,1$ \\
Kebun & $4.552,7$ & $13.657,9$ \\
Padang rumput & 647,8 & 161,9 \\
Sawah & 934,9 & 467,5 \\
Pemukiman & 409,9 & 412,7 \\
Total & $13.809,5$ & $20.725,9$ \\
\hline
\end{tabular}

Sumber: tata guna lahan: Antomi et al., 2016; Beban P hasil perhitungan

Hal ini mengindikasikan bahwa beban cemar TP dari kegiatan budidaya lebih besar yaitu 97,5\% jika dibandingkan dengan beban cemar dari daerah tangkapan air. Beban cemar TP di Danau Taechung, Korea Selatan yang 
merupakan lokasi budidaya ikan menunjukkan bahwa beban TP dari luar perairan sebesar 68\% (Kwang-Guk \& Dong-Su, 2003). Beban cemar TP di Danau Maninjau sebesar 95\% berasal dari kegiatan budidaya (Henny \& Nomosatryo, 2016). Estimasi konsentrasi TP diperairan sebagai akibat beban cemar TP dari DTA yaitu $16,14 \mu \mathrm{g} / \mathrm{L}$. Jika beban cemar hanya berasal dari daerah tangkapan air maka status kesuburan perairan Danau Maninjau adalah mesotrofik. Beban cemar TP yang rendah ini karena DTA didominasi oleh kawasan hutan dan kebun yaitu masingmasing sebesar 39,4 dan 33,3\%. Badan air dengan tata guna lahan yang didominasi oleh hutan cenderung mempunyai status kesuburan yang rendah (Sulastri et al., 2008).

Untuk menurunkan status trofik Danau Maninjau perlu adanya suatu upaya untuk mengurangi beban cemar TP (Nikolai \& Dzialowski, 2014). Beban cemar TP yang maksimal yang dapat ditampung pada kondisi kesuburan perairan mesotrofik adalah sebesar 32 ton/tahun. Jika beban cemar TP dari dearah tangkapan air sebesar 20 tonP/tahun maka alokasi untuk kegiatan budidaya adalah sebesar 12 tonP/tahun. Alokasi Beban TP ini sebanding dengan produksi ikan sebesar 821 ton ikan/tahun. Jika mengacu pada produksi untuk setiap petak KJA maka jumlah KJA yang boleh beroperasi sebanyak 781 petak.

\section{SIMPULAN}

Beban fosfor dari kegiatan budidaya di Danau Maninjau sebesar 693,4 ton/tahun sedangkan dari daerah tangkapan air sebesar 20 ton/tahun. Hal ini berdampak pada status kesuburan perairan Danau Maninjau menjadi hipertrofik dengan konsentrasi total $\mathrm{P}$, klorofil- $a$ masing-masing adalah 540 dan 41,4 $\mu \mathrm{g} / \mathrm{L}$ dengan tingkat kecerahan 1,1 m. Hal ini menggambarkan bahwa beban cemar TP telah melebihi daya dukung ekologi perairan Danau Maninjau yaitu sebesar 223,4 ton/tahun.

\section{DAFTAR PUSTAKA}

1. Afrin, J. Hendrik. Nugroho F. 2015. Analisis usaha pembesaran ikan nila (Oreochromis niloticus) dalam keramba jaring apung (KJA) di Nagari Tanjung Sani Kecamatan Tanjung Raya Kabupaten Agam Provinsi Sumatera Barat. JOM 8: 1-11

2. Ahmed R. Shahabuddin AM. Habib MAB. \& Yasmin M S. 2010. Impact of aquaculture practices in Naogaon District of Bangladesh. Research Journal of Fisheries and Hydrobiology 5(2): 56-65

3. AntomiY. Martono DM. Suparmoko M. Koestoer RH. 2016. Water quality index in Lake Maninjau as a parameter to determine the optimum economic growth of floating net cages and Landbased Livelihood. OIDA International Journal of Sustainable Development 9(2): 51-62

4. APHA (American Public Health Association). 2005. Standar Methods for the Examination of Water and Waste Water Including Bottom Sediment and Sludges. $21^{\text {st }}$ edition. In: Eaton AD, Clesceri LS, Rice EW, Grennberg AE. Amer. Publ. Health Association Inc. New York. 1296p

5. Aries SA. Syandri H. Suparno. 2015. Kondisi fisika-kimia dan pembebanan sedimen di perairan Danau Maninjau untuk kelangsungan usaha perikanan keramba jaring apung. Jurnal Program Pasca Sarjana Universitas Bung Hatta 7(1): 1-14 
6. Badr NBE. Hussein MA. 2010. An input/output model of total phosphorus in Lake Edku, a Northern Eutrophic Nile Delta Lake. Global Journal of Environmental Research 4(2): 64-75

7. Beveridge MCM. 2004. Cage Culture. Third Edition. Blackwell Publishing. $368 p$

8. Brett MT. Benjamin MM. 2008. A review and reassessment of lake phosphorus retention and the nutrient loading concept. Freshwater Biology 53: $194-211$

9. Cunha DGF. Calijuri MDC. Lamparelli MC. 2013. A trophic state index for tropical/subtropical reservoirs (TSI ${ }_{\text {tsr }}$ ). Ecological Engineering 60: 126-134

10. Degefu F. Mengistu S. Schagerl M. 2011. Influence of fish cage farming on water quality and plankton in fish ponds: A case study in the Rift Valley and North Shoa reservoirs, Ethiopia. Aquaculture 316: 129-135

11. De Anda J. Shear H. Maniak U. Riedel G. 2001. Phosphate in Lake Chapala, Mexico. Lakes \& Reservoirs: Research and Management 6: 313-321

12. Fakhrudin M. 2003. Kajian ekohidrologi sebagai dasar untuk pengelolaan Danau Maninjau Sumatera Barat. Tanjung, S. D., Hadisusanto, S., Puspito, A. (editors). Prosiding Seminar Nasional Limnologi: 191-209.

13. Garno YS. 2002. Beban pencemaran limbah perikanan budidaya dan yutrofikasi di perairan waduk Das Citarum. Jurnal Teknologi LIngkungan 3(2): 112-120

14. Guo L. Li Z. 2003. Effect of nitrogen and phosphorus from fish cage-culture on communities of shallow lake in middle Yangtze River basin of China. Aquaculture 226: 201-212
15. Henny C. Nomosatryo S. 2016. Changes in water quality and trophic status associated with cage aquaculture in Lake Maninjau, Indonesia. Conf. Series: Earth and Environmental Science 31: 1-9

16. Jhones PJ. 1996. Evaluation and management of the impact of land use change on the nitrogen and phosphorus load delivered to surface waters: the export coefficient modelling approach. Journal of Hydrology 183: 323-349

17. Jones RA. Rast W. Lee GF. 1979. Relationship between summer mean and maximum chlorophyll $a$ concentration in lakes. Environmental Science \& Technology 13: 869-870

18. Johnson DL. Nielsen LA. 1985. Sampling considerations. In: Nielson LA. Johnson DL, Editors. Fisheries Techniques. Maryland: American Fisheries Society: 1-21

19. Jorgensen SE. 1988. Fundamental of ecological modelling. Elsiver. Ansterdam. 391

20. Junaidi. Syandri H. Azrita. Basri Y. 2013. Trophic status and potenstial production estimates of fish littoral waters Maninjau Lake West Sumatra. Dalam Hutahuruk, R., et al (Editors). Proceeding $2^{\text {nd }}$ National and International Seminar of Fisheries and Marine: 85-91

21. KibriaG. Nugegoda D. Lam P. Fairclough, R. 1996. Fairclough. Aspect of phosphorus pollution from aquaculture. Naga The ICLARM Quarterly 19(3): 20 - 24p

22. Krismono. 1992. Hubungan antara tingkat trofik dengan produksi keramba jaring apung mini di suatu bdan air. Bull. Pen. Perikanan 1: 45-50

23. Kwang-Guk A. Dong Su K. 2003. Response of reservoir water quality to nutrient inputs from streams and in-Like Fishfarms. Water, Air, and Soil Pollution 149: 27-49 
24. Lazzari R. Baldisserotto. 2008. Nitrogen and phosphorus waste in fish farming. $B$. Inst. Pasca, Sao Paulo 34(4): 591-600.

25. Lee GF. Rast W. Jones RA. 1978. Eutrophication of water bodies: Insights for an age-old problem: New information enables water quality managers to predict reliably water quality changes that result from various phosphate control management practice. Environmental Science and Technology 12:900-908

26. Lukman. Sutrisno. Hamdani A. 2013. Pengamatan pola stratifikasi di Danau Maninjau sebagai potensi Tubo Belerang. Limnotek 20(2): 129-140

27. Machbub B. 2010. Model perhitungan daya tampung beban pencemaran air danau dan waduk. Jurnal Sumber Daya Air 6(2): 103-204

28. Marganof. Darusman. LK. Riani E. Pramudya, B. 2007. Analisis beban cemar, kapasitas asimilasi dan tingkat pencemaran dalam upaya pengendalian pencemaran perairan Danau Maninjau. Jurnal Perikanan dan Kelautan 12(1): 8-14

29. Nasution Z. Sari YD. Huda HM. 2011. Perikanan budidaya di Danau Maninjau: Antisipasi kebijakan penanganan dampak kemayian masal ikan. $J$. Kebijakan Sosial Ekonomi Kelautan dan Perikanan 1(1): 19-31

30. Neumeier U. Friend PL. Gangelhof U. Lunding J. Lundkvist M. Bergamasco A. Amos CL. Flindt M. 2007. The influence of fish feed pellets on the stability of seabed sediment: A laboratory flume investigation. Estuarine, Coastal and Shelf Science 75: 347-357

31. Nikolai, SI. Dzialowski AR. 2014. Effect of internal phosphorus loading on nutrient limitation in a eutrophic reservoir. Limnologica 49: 33-41
32. Palys T. 2008. Purposive sampling. In Given, L. M (Edt). The Sage Encyclopediaof Qualitative Research Methods 2 Sage. Los Angeles: 697-698

33. Rast W. Lee GF. 1983. Nutrient loading estimates for lakes. Journal of Environmental Engineering 109(2): 502-518

34. Rast W. Jones RA. Lee GF. 1983. Predictive capability of U.S.OECD phosphorus loading-eutrophication response models. Journal WPCF 55(7): 990-1003

35. Roesma DW. 2013. Evaluasi keanekaragaman spesies ikan di Danau Maninjau. Prosiding Semarata FMIPA Universitas Lampung 1(1): 197-2014

36. Ryding SO. Rast W. 1989. The control of of eutrophication of lakes and reservoirs. The Parthenon Publishing Group. United Kingdom: 314

37. Sitompul F. Ramli M. Bathara L. 2015. Analisa keadaan usaha budidaya ikan sistem keramba jaring apung (KJA) di Danau Toba (Kasus Desa Untemungkur Kecamatan Muara Kabupaten Tapanuli Utara Provinsi Sumatera Utara. JOM 2(1): $1-10$

38. Smith VH. Tilman GD. Nekola JC. 1999. Eutrophication: impact of excess nutrient input on freshwater, marine, and terrestrial ecosystems. Environmental Pollution 100: 179-196

39. Sulastri. Harsono E. Suryono T. Ridwansyah I. 2008. Relationship of land use, water quality anad phytoplankton community of some small lakes in West Java. Oseanologi dan Limnologi di Indonesia 34(2): 307-332

40. Sulastri. Hartoto DI. Yuniarti I. 2012. Environmental condition, fish resources and management of Maninaju Lake of West Sumatera. Ind. Fish Res. J. 18(1): 1-15 
41. Sulastri. Nomosatryo S. Hamdani A. 2016. Kondisi lingkungan perairan dan keanekaragaman sumberdaya ikan di Danau Maninjau, Sumatera Barat. Bawal 8(1): 1-12

42. Suyani H. Deswati. Refilda. Sutopo J. 2016. Water quality analysis of postevent up welling and step anticipation in aquaponics locations of Maninjau Lake. Der Pharma Chemica 8(10): 102-108

43. Syandri H. Elfiondri. Azrita. 2015. Social status of fish farmers of floating net cages in Lake Maninjau, Indonesia. J. Aquac Res Development 7(1): 1-5

44. Syandri H. Azrita. Niagara. 2016. Trophic status and load capacity of water pollution waste fish culture with floating net cages in Maninjau Lake, Indonesia. Eco. Env. \& Cons 22(1): 469-476

45. Syandri H. Azrita. Mardiah A. 2018. Nitrogen and phosphorus waste production from different fish species cultured aat floating net cages in Lake Maninjau, Indonesia. Asian Journal of Scientific Research 11: 287-294

46. Tamba S. Ramli M. Hendrik. 2014. Analisa kelayakan budidaya ikan nila (Oreochromis niloticus) dalam keramba jaring apung di Desa Silalahi III Kecamatan Silahibungan Kabupaten Dairi Provinsi sumatera Utara. JOM 1(1): 1-11
47. Triyanto. Lukman. Meutia AA. 2005. Introduksi keramba jaring apung berlapis sebagai alternative sistem pemeliharaan ikan dalam keramba ramah lingkungan di Danau Maninjau Sumatera Barat. Limnotek XII (2): 61-67

48. True B. Johnson W. Chen S. 2004. Reducing phosphorus discharge from flow-through aquaculture I: facility and effluent characterization. Aquaculture Engineering 32: 129-144

49. Yuniarti I. Hartoto DI. Sulastri. Triyanto. Sutrisno. 2009. KO-Manajemen dalam pengelolaan perairan darat Indonesia: sebuah pembelajaran dari pengelolaan Danau Maninjau secara ko-manajemen. Prosiding Forum Nasional Pemacuan Sumberdaya Ikan II: 1-12

50. Yuniarti I. Sulastri. Sutrisno. 2010. Jaring-jaring makanan di Danau Manianjau. Dalam Wibowo, H., LUkman \& Sulastri (Edits). Prosiding Seminar LImnologi $V$ : 135-144 